\title{
Sustainable futures: Multi-disciplinary perspectives on multi-level transitions
}

DOI:

10.1016/j.envdev.2012.03.002

Link to publication record in Manchester Research Explorer

\section{Citation for published version (APA):}

Dendler, L., Sharmina, M., Calverley, D., \& Traut, M. (2012). Sustainable futures: Multi-disciplinary perspectives on multi-level transitions. Environmental Development, 2(1), 2-5. https://doi.org/10.1016/j.envdev.2012.03.002

\section{Published in:}

Environmental Development

\section{Citing this paper}

Please note that where the full-text provided on Manchester Research Explorer is the Author Accepted Manuscript or Proof version this may differ from the final Published version. If citing, it is advised that you check and use the publisher's definitive version.

\section{General rights}

Copyright and moral rights for the publications made accessible in the Research Explorer are retained by the authors and/or other copyright owners and it is a condition of accessing publications that users recognise and abide by the legal requirements associated with these rights.

\section{Takedown policy}

If you believe that this document breaches copyright please refer to the University of Manchester's Takedown Procedures [http://man.ac.uk/04Y6Bo] or contact uml.scholarlycommunications@manchester.ac.uk providing relevant details, so we can investigate your claim.

\section{OPEN ACCESS}




\section{Sustainable futures: Multi-disciplinary perspectives on multi-level transitions}

What is the disparity between the climate and resource challenges we face and the measures in place to meet them? This special issue addresses that question by outlining various aspects of current problems, more sustainable alternatives and elements of transition pathways to achieve a more sustainable future.

Twenty five years ago the Brundtland Commission highlighted the urgent need to address poverty and align the promotion of human well-being with the protection of the natural environment (UN, 1987). Since 1987 this goal has "acquired a preeminent status in all environmental policies" (Zaccai, 2012) and has been affirmed by various organisations from the corporate, civil society, non-governmental and governmental sphere at national, supra national and international levels. This summer in Rio de Janeiro the international community is going to reflect on this process and on the global commitment to integrate ecological recovery and resilience, inter- and intra-generational equality and development.

Since 1987, a widespread agreement has been achieved on a current mismatch between the earth's finite resources and humanity's increasing demands. There is a broad scientific consensus that fossil fuel dependent lifestyles of industrialised nations and a steep upwards trend in greenhouse gas emissions in industrialising nations (Anderson and Bows, 2011) are increasingly in tension with commitments to curbing climate change (Rogelj et al., 2010; Stern and Taylor, 2010). Climate is one of nine 'planetary boundaries' that define a safe operating space for humanity (Rockström et al., 2009), many of which are currently threatened by large-scale global changes to the biophysical and biogeochemical environment influenced by natural developments and human activities (Dellas et al., 2011).

Whereas a consensus on the need for systemic transformation away from current unsustainable practices has proven to be possible, it appears more difficult to agree on how a more sustainable future could be achieved. Sustainable development implies normative dimensions that are open to interpretation, giving rise to debate, for example, about what is actually entailed by notions of interand intra-generational equity, well-being and human needs (e.g. Daly et al., 1999). The concept of sustainable development is also ambiguous with regards to the relative priority of ecological, economic and socio-cultural aspects of development. According to Zaccai (2012), "the interpretation of sustainable development has always been a kind of game that academic, political and social actors can play, because of its openness and plasticity to every context".

To cross the divide between 'where we want to be' and 'where we are heading', current societal structures and paradigms are likely to require radical changes. Such transitions offer nontrivial challenges due to distinct characteristics of natural and social systems, and there is a need to test the power and the limits of the ambiguous sustainable development concept on an operational level.

The first such characteristic is 'multiplicity' maintaining that sustainable futures and ways to achieve them vary across multiple levels (from local to global and from biophysical to institutional), sectors (e.g. energy, transportation, agriculture, food systems, waste management) and regions. The second 
characteristic includes interdependencies, i.e., functional and spatial reciprocal relations between different natural and social subsystems as well as between their multiple elements (e.g. links between climate change and biodiversity). This also comprises time interdependencies, since cause and effect of earth system transformations are usually separated by decades, often by generations, which makes sustainable development a long-term, open-ended project. Third, although there is some agreement on the causes of global environmental change, uncertainty persists regarding its impacts, the interlinkage of various causes and response options, which bring about new risks that cannot be anticipated. Fourth, sustainable development can involve trade-off decisions on highly contested issues. A sustainable solution for one element of the system might have unsustainable consequences elsewhere. These trade-offs are amplified by the potentially extreme impacts of current (or potential) transformation in the earth system, which could cause extraordinary degrees of harm (Kemp and Martens, 2007; Biermann, 2007).

Consequently, moving beyond problem identification and definition into analysing societal changes needed to achieve a more sustainable future invites further debate and a multiplicity of potential paths. To allow for such multiple paths towards different futures and address the challenges outlined above, many authors point to the need for new forms of governance. Governance can be understood in several ways. A notion that has recently gained popularity amongst sustainability scholars and is directly relevant to this special issue is 'earth system governance', defined as "the sum of the formal and informal rule-systems and actor-relationships at all levels of human society that are set up in order to influence the co-evolution of human and natural systems in a way that secures the sustainable development of human society" (Biermann, 2007). Earth system governance is multi-layered and fragmented. It covers not only problems of the 'global commons', but also local problems from air pollution to soil degradation and involves a myriad of public and private non-state actors at all levels of decision-making (Biermann, 2007; Dellas et al., 2011).

Accordingly the problems, futures and transitions to achieve these futures interweave and, foregrounding the multiplicity, involve the following:

- multiple levels (from physical to institutional);

- multiple spatial scales (global to local);

- multiple regions (different parts of the world);

- multiple actors (from public to private).

This special issue sheds light on the multiple dimensions of transitioning to sustainable futures, presenting outcomes of an international conference organised by doctoral students at the Tyndall Centre for Climate Change Research and the Sustainable Consumption Institute at the University of Manchester. The conference took place on the 30th-31st March 2011 and brought together researchers from a wide range of disciplines and institutions including social scientists, physical scientists and engineers to discuss necessary changes to achieve a more sustainable future. The contributions therefore span a range of disciplines, methodologies and problem-solving styles. Such a shift towards interdisciplinarity is in line with the call for a 'sustainability science' and is especially appropriate when aiming to address the multidimensional character of sustainable development and earth system governance (e.g. Kemp and Martens, 2007; Biermann, 2007).

The first two articles of the special issue question traditional top-down steering methods to achieve a more sustainable future. Rooted in the analysis of national (UK) level policies and emission trends in the residential sector, James investigates the shortcomings of existing and proposed policy frameworks aimed at household energy savings. He presents new structures to overcome these shortcomings, suggesting that current policies need to become more flexible and to accommodate a more intensive involvement of residents. The paper concludes that re-organising the energy market and gearing towards 'safe operating space' can bring about a sustainable paradigm shift.

Similarly, Cohen points to the inadequacy of centralised top-down attempts to affect action on climate change. He highlights the importance of participation and inclusiveness and discusses the process of citizen participation in choosing between alternative means to pursue a sustainable future, given trade-offs between the emissions saving potential of various mitigation measures. The paper looks for solutions to the political impasse with regard to generating effective action on 
climate change at the level of individuals, and by identifying interconnections between common ownership of goals and the creation of political mandates.

The subsequent papers follow suit, emphasising different aspects and related challenges of participation within multilevel governance transitions towards more sustainable futures. For instance, Rawson et al. examine two case studies on how major UK airports have implemented a stakeholder engagement process required for them to produce master plans for further expansion. Showing how both fall short of raising stakeholder participation onto a level of meaningful influence, the authors go on to argue that a higher degree of involvement of different actor groups could lead to more sustainable planning outcomes as well as social and environmental consequences they entail.

Preston's paper considers challenges presented by the inclusion of international aviation within the European Union's emissions trading scheme (EU ETS) from 2012 onwards, with a reference to various scales, regions and levels at which actors within the global aviation industry operate. The paper suggests that efficiency gains in aircraft and fuels are unlikely to offset emission growth from unrestrained demand for aviation. It then examines remaining uncertainties around quantifying and controlling the non- $\mathrm{CO}_{2}$ emissions from aviation. The paper concludes with reflections on potential barriers to the effectiveness of emissions trading schemes at different geopolitical scales and with regulatory authority residing in a variety of institutions.

Drawing on the insights from the history of geoengineering, the paper by Welch et al. explores scientific foundations and governance issues of climate manipulation. The article demonstrates that geoengineering can potentially become an important part of a multi-faceted response to a changing climate, provided clear communication strategies and governance structures are put in place. The authors acknowledge multiple uncertainties and trade-offs involved in the implementation of geoengineering proposals and suggest that an active debate, consultation and participation, supported by the interdisciplinary mandate of UNESCO, is the way forward.

Broadening the focus from participation to related notions of accountability and legitimacy, Guarnacci's contribution shows how current disaster reconstruction is arguably unsustainable and needs to better coordinate its inclusiveness and accountability through network governance, effective evaluation, community engagement and knowledge sharing. In so doing, the author expands the focus to another core aspect of a transition towards more sustainable futures and earth system governance: the concept of adaptive capacity.

Berman et al. provide a framework for this concept integrating the role of institutions. The authors' innovative framework allows for a transition from 'coping' towards a more sustainable 'adaptive' capacity and for what they argue to be a necessary bridging of the traditions of vulnerability and resilience.

Finally, the article by Trutnevyte et al. applies the concept of participation to the core theme of this special issue by developing a novel approach to the process of envisioning futures, with an emphasis on the role of different stakeholders in a society and the plurality of visions. Presenting the process by which the Swiss community of Urnäsch brings together representatives of relevant stakeholder groups to deliberate on alternative energy scenarios, the paper focuses on how scenarios are perceived by different actor groups and how these perceptions change over time. Trutnevyte et al. explore the possible, explicitly accounting for the complexity that arises from different actors assessing problems characterised by all of the challenges mentioned earlier: multiplicity, interdependencies, uncertainties and involved trade-offs.

The papers in this special issue address different aspects of the pathways towards more sustainable futures. They each proceed from identifying unsustainable development on a specific level, space, region and/or amongst specific actors, to then highlighting facets of a potential alternative future state, either in the form of resolving that particular problem or as a vision of an overarching sustainable future. With regard to transitions, each article refers to shifts in governance approaches needed to achieve these alternative futures. This can be a transition specific to a certain level, space, region or actor or a transition across these multiple dimensions. A core theme cutting across most of the articles is the need for greater participation as well as the necessity to find solutions to the challenges such participation poses. This is very much in line with dominant discussions within the earth system governance literature, which sees participatory forms of governance as one of the key aspects of more sustainable futures and a part of a strong "normative trend to democratise global governance schemes" (Bernstein, 2005). It is also another sign of the increasing subsumption of participation and civility under the normative sustainable development umbrella. 
Rather than attempting to paint a complete or definitive picture of a sustainable future, this special issue aims to shed light on the varied pathways towards different parts of such futures, to stimulate debate on the interface of science and policy and to inspire others who are on the same track.

\section{References}

Anderson, K., Bows, A., 2011. Beyond dangerous climate change: emission pathways for a new world. Philosophical Transactions of the Royal Society A 369 (1934), 20-44.

Bernstein, S., 2005. Legitimacy in global environmental governance. Journal of International Law and International Relations 1 (1-2), 139-166.

Biermann, F., 2007. 'Earth system governance' as a crosscutting theme of global change research. Global Environmental Change 17 (3-4), 326-337.

Daly, Herman E., Cobb, John B., Cobb, Clifford W., 1999. For the Common Good: Redirecting the Economy Toward Community, the Environment, and a Sustainable Future, 2nd ed. Beacon Press, Boston (updated and expanded).

Dellas, E., Pattberg, P., Betsill, M., 2011. Agency in earth system governance: refining a research agenda. International Environmental Agreements: Politics, Law and Economics 11 (1), 85-98.

Kemp, R., Martens, P., 2007. Sustainable development: how to manage something that is subjective and never can be achieved? Sustainability: Science, Practice, \& Policy 3 (2), 1-11.

Rockström, J., Steffen, W., Noone, K., et al., 2009. Planetary boundaries: exploring the safe operating space for humanity. Ecology and Society 14 (2). (art. 32).

Rogelj, J., Nabel, J., Chen, C., Hare, W., Markmann, K., Meinshausen, M., Schaeffer, M., Macey, K., Hohne, N., 2010. Copenhagen Accord pledges are paltry. Nature 464 (7292), 1126-1128.

Stern, N., Taylor, C., 2010. What do the Appendices to the Copenhagen Accord tell us about Global Greenhouse Gas Emissions and the Prospects for Avoiding a Rise in Global Average Temperature of more than $2{ }^{\circ} \mathrm{C}$ ?. The Centre for Climate Change Economics and Policy (CCCEP) the Grantham Research Institute on Climate Change and the Environment, London, UK.

UN, 1987. Report of the World Commission on Environment and Development. Our Common Future. Available from: 〈http:// www.worldinbalance.net/pdf/1987-brundtland.pdf $>$ (01.05.08).

Zaccai, E., 2012. Over two decades in pursuit of sustainable development: influence, transformations, limits. Environmental Development 1 (1), 79-90.

Leonie Dendler

Sustainable Consumption Institute, University of Manchester, UK

Tyndall Centre for Climate Change Research, UK

Manchester Institute of Innovation Research, Manchester Business School, UK

Maria Sharmina*

Sustainable Consumption Institute, University of Manchester, UK

Tyndall Centre for Climate Change Research, UK E-mail address: maria.sharmina@manchester.ac.uk

Dan Calverley, Michael Traut

Tyndall Centre for Climate Change Research, UK

${ }^{*}$ Corresponding author at: Sustainable Consumption Institute, University of Manchester, UK. 